\title{
Testicular shape and andrological aspects of young Nellore bulls under extensive farming
}

\section{Jeanne Broch Siqueira ${ }^{1}$, Eunice Oba ${ }^{1}$, Rogério Oliveira Pinho ${ }^{2}$, Simone Eliza Facioni Guimarães ${ }^{2}$, Tamires Miranda Neto $^{3}$, José Domingos Guimarães ${ }^{2}$}

\author{
1 Faculdade de Medicina Veterinária/UNESP - Botucatu/SP/Brazil. \\ 2 Universidade Federal de Viçosa. \\ ${ }^{3}$ Agro-Pecuária CFM/Brazil.
}

\begin{abstract}
Aiming to determine the relationship between the frequency of testicular shape and the andrological aspects in young Nellore bulls, 18,676 animals were assessed. All andrological examinations were performed between the years 2000 and 2008. Animals were classified as able for breeding, able for breeding in natural mating system, unable for breeding and discarded. The testicular shape was classified as long, fairly long, oval-long, spherical-oval, and spherical. The analysis of Pearson correlations was performed for testicular shape with scrotal circumference, testicular volume, progressive motility, sperm vigor, major defects, minor defects and total defects. Testicles with oval shape prevailed (99.61\%). It was obseved that $76.34 ; 66.34 ; 64.34 ; 58.33$ and $50.00 \%$ of the animals were classified as sound for breeding for shapes long, fairly long, ovallong, spherical-oval, and spherical, respectively. Correlations between testicular shape with scrotal circumference, testicular volume, progressive motility, sperm vigor, major, minor and total defects were $0.26 ; 0.08 ; 0.00 ; 0.11 ;-0.02 ; 0.02$ and -0.01 , respectively. Testicular shape had no influence upon the andrological examination results. Testicles of long shape were prevalent within the population.
\end{abstract}

Key Words: bovine, semen, testicular measurements

\section{Introduction}

The rate of approximately $70 \%$ of Zebu animals and their crosses in the Brazilian cattle population corresponds to over 173 million (ANUALPEC, 2010). In Brazil, among the Zebu breeds, Nellore is the one that has been studied with the aim of identifying good selection criteria (Lira et al., 2008).

The performance of the breeding depends on the improvement of management techniques and nutrition, but the physiology of testicular development and weight are also crucial, in addition to the factors that potentially interfere with these processes, such as sexual precocity and the ability of sperm production (Moura et al., 2002). The scrotal circumference has been the most widely used and studied criterion in screening programs as a measure indicative of morphological and physiological characteristics of gonads and quantitative and qualitative characteristics of semen in cattle (Forni \& Albuquerque, 2004).

The prevalence of long testicular shape in Zebu males, particularly Nellore, according to scrotal circumference usually small, has gotten farmers preoccupied about selecting their breeders. This fact is due largely to the selection criteria adopted by the scrotal circumference, so that males with long testicles can be eliminated because they had less girth than their contemporaries of oval testicles (Unanian et al., 2000).

Bailey et al. (1996) suggested that scrotal circumference might not be the most appropriate measure to represent the sperm production of young bulls and, consequently, the reproductive potential of these animals. According to these authors, longer testis present greater contact surface with the environment, which facilitates thermoregulation, in addition to the distribution of blood vessels and the spermatic tissue is uniform, thus the more elongated testicular forms would be more advantageous for reproduction.

However, studies have suggested the use of testicular volume as a complementary measure to scrotal circumference, in the interests of improving accuracy in the evaluation of breeding, since some studies have suggested that only scrotal circumference could not state with certainty the reproductive potential of the bull (Unanian et al., 2000). The objective of this study was to determine the frequency of testicular shape and its relation to andrological aspects in Nellore young bulls. 


\section{Material and Methods}

Eitghteen thousand six hundred and seventy six Nellore young bulls from the herd of five properties of Agro-Pecuária CFM Ltda., Brasil (20³8' 38"; 20 17' 57"; $21^{\circ} 12^{\prime} 32^{\prime \prime} ; 20^{\circ} 08^{\prime} 30^{\prime \prime}$ and $20^{\circ} 40^{\prime} 47^{\prime \prime}$ south latitude of the Equator, respectively for the five properties studied, and 50 13' 34"; 49 43' 54"; 50 25' 58"; 54²3'58"; 55 17' 46" west longitude of Greenwich, respectively for the five properties studied) were used in the experiment. The Bulls, with mean age of 21.29 months, were evaluated by andrological examinations in the months of June to August from 2000 to 2008, corresponding to the seasons 1998 to 2006. All animals were raised on pasture, predominantly Brachiaria decumbens grass $(40 \%)$ and Panicum maximum (50\%), and with mineral salt and water ad libitum. When bulls reached the age group 18-22 months, they were confined and fed corn silage, mineral salt and water ad libitum.

At the andrological examination, after individual containment of animals, in appropriate trunks, testicular measurements were performed, which comprised length and width of testis, scrotal circumference and testicular consistency of classification. Measurements for length and width of testis were obtained with the aid of caliper rule, and the length measured in the longer sense the gonad (dorsal-ventral), including the head, excluding the tail of the epididymis, and the breadth in the wider region of the gonad the lateral-medial direction were achieved using the body of the animal as reference. The scrotal circumference at the time of andrological examination was obtained with the aid of tape, after mild ventral-caudal traction of the gonads and in the wider region of the scrotum (CBRA, 1998).

For determination of testicular shape, the authors used the criteria described by Bailey et al. (1996) where the gonads are classified as long (ratio $\leq 0.5$ ), long / moderate (ratio $\leq 0.65$ ), long / ovoid (ratio $\leq 0.75$ ), ovoid / spherical (ratio $\leq 0.86$ ) and spherical (ratio $>0.86$ ). The inclusion of each animal in these classes was done by obtaining the ratio from the medium testicular width (widths of left and right testis) and medium testicular length (average lengths of the left testicle and right).

To calculate the volume, the formula proposed by Fields et al. (1979) for cylindrical shape was used, as follows: $\mathrm{Vol}=2\left[\left(\mathrm{r}^{2}\right) \times \pi \times \mathrm{L}\right]$, where: $\mathrm{r}=$ radius of testicular width; $\pi=$ correction factor and $\mathrm{L}=$ testicular length. Otherwise, the formula for spherical shape, as recommended by Bailey et al. (1998), where: $\mathrm{vol}=4 / 3(\mathrm{p})(\mathrm{L} / 2)(\mathrm{w} / 2)^{2}$ where: $\mathrm{w}=$ testicular width; $\mathrm{p}=$ correction factor and $\mathrm{L}=$ testicular length.
For obtainment of semen, the method of electroejaculation was used. After collection, the physical characteristics of the ejaculate of mass motility, progressive motility (0-100\%) and the sperm vigor (0-5) were examined on a 1-5-scale. For morphological analysis of sperm, a semen sample was wrapped and stored in $1 \mathrm{~mL}$ of buffered formaldehyde saline (Hancoch, 1957). In this evaluation, the methodology recommended by Blom $(1973,1983)$, was adopted, recording the head defects, tail and acrosome, and classifying abnormalities in major, minor and total defects. Four hundred sperm cells per ejaculate were analysed with the aid of phase contrast microscopy at 1250X magnification.

The determination of age at sexual maturity was done according to Garcia et al. (1987), whose definition was because the animals show major defects ejaculates with less than $15 \%$ and total sperm defects below $30 \%$. In addition to sexual maturity, according to Guimarães (1997), in accordance with study of the spermatogenic process, reproduction pathophysiology and physical and morphological traits of sperm were classified, resulting in five Andrological classes: 1 : sexually mature animal, able to reproduce, according to the standards recommended by CBRA (1998); 2: sexually mature animals, with rates of sperm pathologies without affecting the fertilizing capacity of sperm cells, classified as suitable for breeding under natural mating; 3: sexually immature animals temporarily unable for breeding, 4: animals discarded because of spermiogenesis and morphological changes of the genitals.

For statistical analysis, the SAEG program (Sistema para Análises Estatísticas, versão 9.1) was used, where for all traits studied descriptive statistical analysis (average, standard deviation, variation coefficient) were performed. The frequency and number of animals were classified according to andrological class and testicular shape in all the years studied. The Lilliefors test was used to check normality of responses of the variables. The homogeneity of variances was esudied using the Cochran-Bartlett test. The simple Pearson correlation was used to verify relationships between traits. Analysis of variance and comparisons between means by Tukey test was performed with $5 \%$ probability of error.

\section{Results and Discussion}

The predominant testicular shapes (Table 1) were those elongated in $99.61 \%(18,602)$ of animals: $33.87 \%(6,325)$ long, $54.78 \%(10,230)$ fairly long and $10.96 \%(2,047)$ ovallong. The oval-long testicular shape was recorded in all years, although less frequent $(10.96 \%)$ than the long and fairly long shape (33.87 and 54.75\%, respectively). Overall, 
during the study period, spherical-oval (72 animals/0.39\%, predominantly in 2008) and spherical shapes (2 animals/ $0.01 \%$ ) were rarely observed, demonstrating that these testicular shapes are not common in Nellore cattle.

The testicular shape that was most frequently present in all years, except for 2008, was the fairly long, ranging from $36.85 \%$ (2004) to $78.02 \%$ (2001), depending on the year evaluated. Significant increase in the fairly long shape was observed in 2001, and in oval-long shape, in 2008 (78.02 and $58.58 \%$ for fairly long and oval-long shapes, respectively).

In the two years mentioned above, there was a change of technical evaluators, which affected the testicular frequency. This fact is possible because the testis shape in this study is determined by a mathematical formula (Bailey et al.1996), where it is the ratio between the width and length of the testicles. The measurement of testicular length (length of the longest extension of the gonad in the dorsal-ventral direction, including the head, excluding the tail of the epididymis) presented errors at the time of delimitation and positioning of the caliper in the dorsal region of the head of the epididymis, errors which can reach values of up to $2 \mathrm{~cm}$ because the region is very well planed and adhered to the gonads, unlike the tail of the epididymis, a fact verified in the average values for testicular length (Table 2). Still, in 2008, the higher prevalence of long testicular shapes (long, fairly long and oval-long) over the spherical shapes (spherical-oval and oval) (Table 1) was observed.

It could be observed that in 2001 and 2008 the recorded values for right and left testicular length (10.44 \pm 1.01 , $10.47 \pm 0.99 \mathrm{~cm}$ and $10.45 \pm 0.99$ and $10.45 \pm 0.98$, respectively) were lower $(\mathrm{P}<0.05)$ than all other years, justifying the dominance of fairly long and oval-long shapes, respectively, for the years 2001 and 2008. Additionally, in 2008 the highest values of left and right testicular widths (6.69 \pm 0.60 and $6.68 \pm 0.59$, respectively) were registered, compared with other years $(\mathrm{P}<0.05)$. For the other sampling years, although the numerical values are very close, there were differences between them $(\mathrm{P}<0.05)$, with higher averages in the years 2005, 2006 and 2007.

Averages for length and width of left and right testicles in this study were $11.37 \pm 0.60,11.40 \pm 0.59,6.09 \pm 0.29$ and $6.14 \pm 0.27$, respectively. Silveira et al.(2010) and Vasconcelos

Table 1 - Number of animals and frequency of testicular shape according to the year in Nellore bulls with average 21.29 months bred extensively

\begin{tabular}{|c|c|c|c|c|c|c|c|c|c|c|c|c|}
\hline \multirow[t]{3}{*}{ Year } & \multicolumn{12}{|c|}{ Testicular shape } \\
\hline & \multicolumn{2}{|c|}{ Long } & \multicolumn{2}{|c|}{ Fairly long } & \multicolumn{2}{|c|}{ Oval long } & \multicolumn{2}{|c|}{ Spherical long } & \multicolumn{2}{|c|}{ Spherical } & \multicolumn{2}{|c|}{ Overall } \\
\hline & $\%$ & $\mathrm{n}$ & $\%$ & $\mathrm{~N}$ & $\%$ & $\mathrm{~N}$ & $\%$ & $\mathrm{n}$ & $\%$ & $\mathrm{n}$ & $\%$ & $\mathrm{n}$ \\
\hline 2000 & 27.78 & 460 & 63.29 & 1048 & 8.76 & 145 & 0.18 & 3 & - & - & 8.87 & 1656 \\
\hline 2001 & 9.15 & 213 & 78.02 & 1817 & 12.80 & 298 & 0.04 & 1 & - & - & 12.47 & 2329 \\
\hline 2002 & 35.38 & 715 & 55.91 & 1130 & 8.71 & 176 & - & - & - & - & 10.82 & 2021 \\
\hline 2003 & 51.48 & 1238 & 47.94 & 1153 & 0.54 & 13 & 0.04 & 1 & - & - & 12.88 & 2405 \\
\hline 2004 & 62.52 & 1191 & 36.85 & 702 & 0.63 & 12 & - & - & - & - & 10.20 & 1905 \\
\hline 2005 & 49.93 & 999 & 49.38 & 988 & 0.70 & 14 & - & - & - & - & 10.71 & 2001 \\
\hline 2006 & 44.18 & 957 & 53.88 & 1167 & 1.94 & 42 & - & - & - & - & 11.60 & 2166 \\
\hline 2007 & 26.35 & 538 & 69.34 & 1416 & 4.26 & 87 & 0.05 & 1 & - & - & 10.93 & 2042 \\
\hline 2008 & 0.65 & 14 & 37.61 & 809 & 58.58 & 1260 & 3.07 & 66 & 0.09 & 2 & 11.52 & 2151 \\
\hline Total & 33.87 & 6325 & 54.78 & 10230 & 10.96 & 2047 & 0.39 & 72 & 0.01 & 2 & 100 & 18676 \\
\hline
\end{tabular}

Table 2 - Mean and standard deviation of the testicular lengths and widths of Nellore young bulls with an average of 21.29 months of age, reared extensively in the years 2000 to 2008

\begin{tabular}{|c|c|c|c|c|}
\hline \multirow[t]{2}{*}{ Year } & \multicolumn{4}{|c|}{ Testicular biometry } \\
\hline & LTL (cm) & RTL (cm) & LTW (cm) & RTW (cm) \\
\hline 2000 & $11.18 \pm 1.27 \mathrm{c}$ & $11.25 \pm 1.29 \mathrm{c}$ & $6.05 \pm 0.52 \mathrm{~d}$ & $6.11 \pm 0.54 \mathrm{c}$ \\
\hline 2001 & $10.44 \pm 1.01 \mathrm{~d}$ & $10.47 \pm 0.99 \mathrm{~d}$ & $5.92 \pm 0.46 \mathrm{ef}$ & $5.99 \pm 0.48 d$ \\
\hline 2002 & $11.19 \pm 1.59 \mathrm{c}$ & $11.25 \pm 1.52 \mathrm{c}$ & $5.93 \pm 0.59 \mathrm{~d}$ & $6.03 \pm 0.59 \mathrm{~d}$ \\
\hline 2003 & $11.62 \pm 1.04 \mathrm{~b}$ & $11.65 \pm 1.01 \mathrm{~b}$ & $5.87 \pm 0.56 f$ & $5.94 \pm 0.57 e$ \\
\hline 2004 & $11.69 \pm 1.03 \mathrm{~b}$ & $11.71 \pm 1.01 \mathrm{~b}$ & $5.74 \pm 0.58 \mathrm{~g}$ & $5.79 \pm 0.59 f$ \\
\hline 2006 & $11.92 \pm 1.15 \mathrm{a}$ & $11.90 \pm 1.20 \mathrm{a}$ & $6.16 \pm 0.60 \mathrm{c}$ & $6.16 \pm 0.65 c$ \\
\hline 2007 & $11.95 \pm 1.19 a$ & $11.97 \pm 1.20 \mathrm{a}$ & $6.42 \pm 0.60 b$ & $6.46 \pm 0.60 \mathrm{~b}$ \\
\hline 2008 & $10.45 \pm 0.99 \mathrm{~d}$ & $10.45 \pm 0.98 d$ & $6.69 \pm 0.60 \mathrm{a}$ & $6.68 \pm 0.59 a$ \\
\hline $\mathrm{A} \pm \mathrm{SD}$ & $11.37 \pm 0.60$ & $11.40 \pm 0.59$ & $6.09 \pm 0.29$ & $6.14 \pm 0.27$ \\
\hline
\end{tabular}

LTL - left testis length; RTL - right testicle length; LTW - left testicle width, RTW - right testicle width.

A + SD - overall mean \pm standard deviation $a, b, c, \ldots g$ - Values followed by same lowercase letters in the same column do not differ. 
et al. (2003) found mean values similar to those observed in this study for testicular lengths in 20-22-month old Nellore cattle. Chaves et al. (2007) also reported similar values in Nellore animals with an average age of 44.5 months, $11.2 \pm 0.9$, $11.2 \pm 1.1,7.3 \pm 0.7$ and $7,2 \pm 0.8 \mathrm{~cm}$ in length and width of left and right testicles, respectively, in animals classified as excellent in libido test and very good points for the andrological certification. Lower values for testicles length were obtained by Pastore et al. (2008), with averages of $10.17 \pm 1.22,6.03 \pm 0.89,10.35 \pm 2.36$ and $6.14 \pm 0.86 \mathrm{~cm}$ for length and width of the left and right testicle, respectively, for Nellore animals with an average age of 22-24 months. Also in Nellore animals, but with the age of 18 months, Freneau et al. (2006) and Unanian et al. (2000) had averages of $9.36 \pm 0.88$ and $7.93 \pm 1.12,5.41 \pm 5.4$; and $4.29 \pm 0.58 \mathrm{~cm}$ for length and width of the testicles, respectively.

There was a change in testicular shape between years, and decreased from fairly long shape; and increase in long shape, at the same rate until the year 2004, but long formats continued prevalent in the population. These results corroborate other studies on prevalence of testicular elongated shapes in zebu (Vasconcelos et al., 2003; Dias et al., 2007; Silva, 2009; Silveira et al., 2010), condition credited to the adaptive capacity of this subspecies in tropical conditions (Caldas et al., 1999).

In this study, the frequency of spherical-oval and spherical shapes is irrelevant near the number of animals with the long and fairly long shapes (74 vs. 19602 animals). This may explain the physiological adaptation of Nellore animals to conditions for the tropical-equatorial theory by Bailey et al. (1996), stating that more elongated testicles showed better vascular architecture, with higher surface area and improved venous and arterial distributions, facilitating heat loss to the environment. For the authors, more elongated testicles have a higher temperature gradient between the poles-testis, which is common in animals with excellent seminal standards evaluated by infrared thermography (Kastelic et al., 1997). This testicular formation gives to Bos taurus indicus greater adaptability to tropical climates or environments with high average temperatures (Vale Filho et al. 1986).

There was less scrotal circumference for shapes long, fairly long and oval-long (31.49 $\pm 2.17,32.48 \pm 2.43$ and $33.38 \pm 2.41 \mathrm{~cm}$, respectively) than for the spherical-long and spherical shapes $(34.74 \pm 2.44$ and $33.65 \pm 1.63 \mathrm{~cm}$, respectively; $\mathrm{P}<0.05$; Table 3 ), demonstrating that animals with elongated testicular shapes have a lower scrotal circumference than animals with testicles more rounded, as reported by Bailey et al. (1996) and Unanian et al. (2000). Similar results were observed by Dias et al. (2007) in Nellore cattle at two and three years old. Given the fact that the scrotal circumference is measured in testicular region of larger diameter, it is expected that animals that have smaller testicular width show, therefore, less scrotal circumference.

Testicular volume averages were higher for animals with long, fairly long and oval-long forms (646.73 \pm 160.93 , and $699.97 \pm 196.59699 .58 \pm 198.82 \mathrm{~cm}^{3}$, respectively) than for spherical-oval and spherical shapes $(259.15 \pm 74.75$ and $211.61 \pm 0.00 \mathrm{~cm}^{3}$, respectively) (Table 3). Dias et al. (2007) obtained different results where the animals of 2 years old with long testicles had lower testicular volume, while for animals of 3 years of age, the testicles were not different in testicular volume.

The prevalence of elongated testicular shapes, characteristic of Zebu, particularly Nellore, depending on the scrotal usually small when compared with animals in Europe, has concerned farmers to selecting their breeding. This fact is largely due to the criteria used in selecting by the scrotal circumference size, in which males with long balls can be eliminated by presenting perimeters smaller than their contemporary oval testis (Silva, 2009).

The concept referring to the long testicles aroused the interest in research (Bailey et al., 1996, Bailey et al., 1998) to

Table 3 - Mean and standard deviation of the testicular lengths and widths of Nellore young bulls with an average of 21.29 months of age, reared extensively in the years 2000 to 2008

\begin{tabular}{|c|c|c|c|c|c|}
\hline \multirow[b]{2}{*}{$\mathrm{AC}$} & \multicolumn{5}{|c|}{ Testicular shape } \\
\hline & Long & Fairly long & Oval-long & Spherical-oval & Spherical \\
\hline SC & $31.49 \pm 2.17 b$ & $32.48 \pm 2.43 b$ & $33.38 \pm 2.41 b$ & $34.74 \pm 2.44 \mathrm{a}$ & $33.65 \pm 1.63 \mathrm{ab}$ \\
\hline TV & $646.73 \pm 160.93 b$ & $699.97 \pm 196.59 a$ & $699.58 \pm 198.82 \mathrm{a}$ & $259.15 \pm 74.75 c$ & $211.61 \pm 0.00 c$ \\
\hline P M & $68.01 \pm 14.31 \mathrm{a}$ & $68.11 \pm 1.71 \mathrm{a}$ & $67.85 \pm 13.52 \mathrm{a}$ & $67.19 \pm 13.24 a$ & $72.50 \pm 10.61 \mathrm{a}$ \\
\hline SV & $2.86 \pm 0.53 a$ & $2.94 \pm 0.66 \mathrm{a}$ & $3.09 \pm 0.64 \mathrm{a}$ & $3.12 \pm 0.62 \mathrm{a}$ & $3.25 \pm 0.35 a$ \\
\hline MAD & $16.50 \pm 15.99 a$ & $16.03 \pm 15.23 \mathrm{a}$ & $15.25 \pm 15.64 \mathrm{a}$ & $15.57 \pm 19.54 a$ & $9.75 \pm 4.59 a$ \\
\hline MID & $5.11 \pm 4.67 \mathrm{~b}$ & $5.58 \pm 5.44 \mathrm{a}$ & $5.33 \pm 5.71 \mathrm{ab}$ & $4.55 \pm 5.39 \mathrm{ab}$ & $1.25 \pm 0.35 \mathrm{ab}$ \\
\hline T D & $21.61 \pm 17.68 \mathrm{a}$ & $21.61 \pm 17.18 \mathrm{a}$ & $20.55 \pm 17.52 \mathrm{a}$ & $20.05 \pm 20.78 \mathrm{a}$ & $11.00 \pm 4.95 \mathrm{a}$ \\
\hline
\end{tabular}


verify if the long shape really affects the reproductive potential of males. The authors showed that semen from the long testicles had higher sperm concentration/mL than ovoid testicles, although the latter presented larger perimeters. These studies concluded that only the scrotal perimeter is not sufficient to predict sperm production, which is linked to other factors, such as testicular volume, and the shape of testicles.

Although there were changes in scrotal circumference and testicular volume $(\mathrm{P}<0.05)$ between testis shapes, there was no difference for progressive motility, sperm vigor, major defects and total defects in animals with a mean age of 21.29 months (Table 3), indicating that the testicular conformation did not interfere with physical or morphological characteristics of semen. Thus, the scrotal circumference can be used as an appropriate measure in the prediction of testicular size in Nellore animals, even with the higher frequency of animals with long balls. Dias et al. (2007) obtained similar results in Nellore cattle at two and three years old.

Additionally, it was found that 67.34 and 66.92, 64.34, 58.33 and $50.00 \%$ of the animals were classified as suitable for reproduction for fairly long, oval-long, spherical-oval and spherical testicular shapes, respectively (Table 4). These results indicate that the testicular shape did not interfere in the adoption of animals at the time of andrological examination in bulls with an average age of 21.29 months. It is worth noting that the lower percentage recorded for the animals of oval shape is due to the small number of bulls (two) in this category in all years studied. Corroborating this, Dias et al. (2007) also found that the classification of animals at the andrological examination was not affected by testicular conformation.

Pearson correlations reported in this study between testicular volume with scrotal circumference and testicular volume of 0.26 and $0.08(\mathrm{P}<0.05)$, respectively, were low but significant. Silveira et al. (2010) and Silva (2009) reported values of 0.11 and -0.09 , and 0.19 and not significant value, respectively, for correlations between testicular shape with scrotal circumference and testicular volume. Dias et al. (2007) reported no significant values for correlations between testicular shape and scrotal circumference. However, Viu et al. (2006) reported higher values ( 0.32 and 0.43 between testicular shape with scrotal circumference and testicular volume, respectively), showing that selection for increased scrotal circumference would respond positively correlated to the testicular shape, indicating the possibility of indirect gains for spherical testicular shapes. Conflicting values are normal because it is a categorical variable with few classes, providing high ranges of values for scrotal circumference and testicular volume so that mean values for each class of testicular shape did not differ, except when there was not a normal distribution.

Correlations between testicular shape with progressive motility, sperm vigor, major, minor and total defects with values of $0.00,0.11,-0.02,-0.01$ and 0.02 , respectively, were also low or zero, demonstrating that no party should be neglected in andrological examinations. Similar results were obtained by Viu et al. (2006) with values of -0.06, 0.08, - 0.27 , -0.13 and -0.26 for testicular shape with progressive motility, sperm vigor, major defects, minor defects and total defects, respectively.

Table 4 - Andrological classification system of young Nellore bulls with average of 21.29 months old, reared extensively, according to testicular conformation

\begin{tabular}{|c|c|c|c|c|}
\hline \multirow{3}{*}{ TS } & \multicolumn{4}{|c|}{ Andrological class } \\
\hline & 1 & 2 & 3 & 4 \\
\hline & $\%(n)$ & $\%(n)$ & $\%(n)$ & $\%(n)$ \\
\hline Long & 67.34 (4259) & $9.04(572)$ & 20.24 (1280) & 3.38 (214) \\
\hline Fairly long & 66.92 (6846) & 10.28 (1052) & 19.40 (1985) & 3.39 (347) \\
\hline Oval-long & 64.34 (1317) & 10.55 (216) & 20.86 (427) & 4.25 (87) \\
\hline Spherical-oval & $58.33(42)$ & $5.56(4)$ & $27.78(20)$ & 8.33 (6) \\
\hline Spherical & 50.00 & 50.00 & $0.00(0)$ & $0.00(0)$ \\
\hline
\end{tabular}

\section{Conclusions}

The prevailing testicular shape in Nellore animals with a mean age of 21.29 months was the fairly long. Correlations between testicular shape with testicular, physical and morphological characteristics of semen were low. The selection by scrotal circumference is an appropriate measure in the prediction of testicular size in Nellore animals even with the higher frequency of animals with long balls, indicating with certainty the reproductive potential of the animals, since the shape of the testicles does not affect the sperm quality of bulls. 


\section{References}

ANUÁRIO DA PECUÁRIA BRASILEIRA - ANUALPEC. 16.ed. São Paulo: FNP, 2010. 360p.

BAILEY, T.L.; MONKE, D.; HUDSON, R.S. et al. Testicular shape and its relationship to sperm production in mature Holstein bulls. Theriogenology, v.46, p.881-87, 1996.

BAILEY, T.L.; HUDSON, R.S.; POWE, T.A. et al. Caliper and ultrasonographic measurements of bovine testicles and a mathematical formula for determining testicular volume and weight in vivo. Theriogenology, v.49, p.581-94, 1998.

BLOM, E. Pathological conditions in the genital organs and in semen as ground for rejection of breeding bulls for import or export to and from Denmark, 1958-1982. Nordisk Veterinaer Medicin, v.35, p.105-30, 1983.

BLOM, E. The ultrastructure of some characteristic sperm deffects and a proposal for a new classification of the bull spermiogram. Nordisk Veterinaer Medicin, v.25, p.383-93, 1973.

CALDAS, M.E.; PINHO, T.G.; PINTO, P.A. et al. Avaliação da biometria e morfologia testicular de touros jovens da raça Nelore (Bos Taurus indicus). Revista Brasileira de Reprodução Animal, v.23, p.210-12, 1999.

CHAVES, R.M.; SOUZA, J.A.T.; NASCIMENTO, I.M.R. et al. Avaliação da capacidade reprodutiva de touros da raça Nelore através da classificação andrológica por pontos (CAP) e do teste da libido. Medicina Veterinária, v.1, p.26-32, 2007.

COLÉGIO BRASILEIRO DE REPRODUÇÃO ANIMAL - CBRA. Manual para exame andrológico e avaliação de sêmen animal. 2.ed. Belo Horizonte, 1998. 49p.

DIAS, J.C.; ANDRADE, V.J.; VALE FILHO, V.R.V. et al. Biometria testicular e aspectos andrológicos de touros Nelore (Bos taurus indicus), de dois e três anos de idade criados extensivamente. Veterinária Notícias, v.13, p.31-37, 2007.

FRENEAU, G.E.; VALE FILHO, V.R.; MARQUES JÚNIOR, A.P. et al. Puberdade em touros Nellore criados em pasto no Brasil: características corporais, testiculares e seminais e de índice de capacidade andrológica por pontos. Arquivo Brasileiro de Medicina Veterinária e Zootecnia, v.58, p.1107-15, 2006.

FIELDS, M.J.; BURNS, W.C.; WARNICK, A.C. Age, season and breed effects on testicular volume and semen traits in young beef bulls. Journal of Animal Science, v.48, n.6, p.1229-304, 1979.

FORNI, S.; ALBUQUERQUE, L.G. Avaliação de características biométricas de testículos de bovinos Nelore. In: SIMPÓSIO DA SOCIEDADE BRASILEIRA DE MELHORAMENTO ANIMAL, 5., 2004, Pirassununga. Anais... Pirassununga: Sociedade Brasileira de Melhoramento Animal, 2004. p.110-121.
GARCIA, J.M.; PINHEIRO, L.E.L.; OKUDA, H.T. Body development and semen physical and morphological characteristics of young Guzerá bulls. Ars Veterinária, v.3, p.47-53, 1987.

GUIMARÃES, J.D. Avaliação andrológica e estudos quantitativos e qualitativos da espermatogênese de touros mestiços F1 Holandês x Zebu e Red Angus x Zebu. 1997. 186f. Tese (Doutorado em Ciência Animal) - Escola de Veterinária da Universidade Federal de Minas Gerais, Belo Horizonte.

HANCOCH, J.L. The morphology of boar spermatozoa. Journal Royal Microscopical Society, v.76, p.84-97, 1957.

KASTELIC, J.P.; COOK, R.B.; COULTER, G.H. Scrotal/testicular thermoregulation and the effects of increased testicular temperature in the bull. Veterinary Clinics of North America: Food Animal Practice, v.13, n.3, p.271-82, 1997.

LIRA, T.; ROSA, E.M.; GARNERO, A.V. Parâmetros genéticos de características produtivas e reprodutivas em zebuínos de corte (revisão). Ciência Animal Brasileira, v.9, n.1, p.1-22, 2008.

MOURA, A.A.A.; RODRIGUES, G.C.; MARTINS FILHO, R. Desenvolvimento ponderal e testicular, concentrações periféricas de testosterona e características de abate em touros da raça Nelore. Revista Brasileira de Zootecnia, v.31, n.2, p.934-943, 2002.

PASTORE, A.A.; TONIOLLO, G.H.; LÔBO, R.B. et al. Características biométricas, testiculares, seminais e parâmetros genéticos de touros pertencentes ao programa de melhoramento genético da raça Nelore. ARS Veterinária, v.24, p.134-141, 2008.

SILVA, M.R. Estudo Genético das características andrológicas de touros jovens da raça Nelore. 2009. 93f. Tese (Doutorado em Melhoramento Genético Animal) - Universidade Estadual de São Paulo, Jaboticabal.

SILVEIRA, T.S.; SIQUEIRA, J.B.; GUIMARÃES, S.E.F. et al. Maturação sexual e parâmetros reprodutivos em touros da raça Nelore criados em sistema extensivo. Revista Brasileira de Zootecnia, v.39, n.3, p.503-511, 2010.

UNANIAN, M.M.; SILVA, A.E.D.F.; McMANUS, C. et al. Características biométricas testiculares para avaliação de touros zebuínos da raça Nelore. Revista Brasileira de Zootecnia, v.29, p.136-144, 2000.

VIU, M.A.O.; MAGNABOSCO, C.U.; FERRAZ, H.T. et al. Desenvolvimento ponderal, biometria testicular e qualidade seminal de touros nelore (Bos taurus indicus) criados extensivamente na região centro-oeste do Brasil. Archives of Veterinary Science, v.11, n.3, p.53-57, 2006.

VALE FILHO, V.R.; PINHEIRO, L.E.L.; NASRUR, P.K. Reproduction in zebu cattle. In: MORROW, D.A. (Ed.) Current therapy in theriogenology. 2.ed. Philadelphia: W.B. Saunders Company, 1986. p.437-22.

VASCONCELOS, C.P.; GUIMARÃES, J.D.; GUIMARÃES, S.E.F. et al. Estádio de maturidade sexual em touros da raça Nelore, dos 20 aos 22 meses de idade. Revista Brasileira de Reprodução Animal, v.32, n.2, p.174-176, 2003 